\title{
TOTAL ECONOMIC VALUE OF ENVIRONMENTAL SERVICES, KAMPUNG BLEKOK, SITUBONDO
}

\author{
GHinA SAlSABILA, AmIR SYARIFUdDIN*), AND FEBRI ARIF CAHYO WIBOWO \\ Program Studi Kehutanan Fakultas Pertanian Peternakan Universitas Muhammadiyah Malang Jl. Raya Tlogomas \\ No.246 Malang, Jawa Timur. Phone: +62 341464 318. Indonesia
}

*Email: amir@umm.ac.id

Accepted August 07, 2021 / Approved October 28, 2021

\begin{abstract}
Blekok tourism village has become an ecotourism-based mangrove conservation area based on Situbondo Regent Regulation No. 13 of 2017. In less than 30 years, the mangrove forest has decreased by 50\% this is due to the rapid population growth and lack of information from the community around the mangrove forest area. Decreasing the quality and quantity of mangroves can have an impact on the survival of the surrounding community and ecosystems that have been formed previously, so calculations are needed as a reference in the use of environmental services in the mangrove forest area. The purpose of this study is to determine the value of direct, indirect and optional economic benefits and to determine the value of the total economic benefits of the mangrove ecosystem economy. The method used was observation and interviews as primary data and literature studies as secondary data. The results obtained are the value of direct benefits of IDR. 681.284.900,00 per year obtained from the catch of crabs and ecotourism. The value of indirect use is obtained as much as IDR. 87.336.000,00 per year which is obtained from catching fish and making breakwaters. The value of choice is IDR. 1,399,923.00 (1 USD=IDR. 14.814,00. The total economic value generated by the mangrove forest area of Kampung Blekok is IDR. 1.027.904.350,00 per year.
\end{abstract}

Keywords: Blekok Village, economy, mangrove forest

\section{INTRODUCTION}

The mangrove forest is the vegetation that grows along the coast (Sambu et al., 2018). Mangrove forest itself becomes a green belt that can break sea water waves (breakwater). Mangrove forest are also the largest carbon producer, more than forests in general, and mangrove forests can withstand high salinity between 0$35 \%$ in tidal conditions (Sulistiyowati, 2009). The high glut of food and shelter, as well as low predation pressure, causes the mangrove ecosystem to form an ideal habitat for various animal species and aquatic biota, for part or all of their life cycle (Buwono et al., 2015).

In human life and other living things, mangrove forest has the main function of balancing the ecosystem and providing various living needs for human beings and other living things (Hairunnisa et al., 2018). Mangrove forest resources are not only known to have economic potential as a provider of wood resources but also as a spawning ground, nursery ground, and also as a feeding ground for fish and other marine biota, and serves to withstand sea waves and sea water intrusion towards the land (Suzana et al., 2011).

The amount of benefits that exist in the mangrove forest ecosystem, has consequences for the mangrove forest ecosystem itself, namely the increasing level of exploitation of the environment which often ends in quite severe environmental degradation (Setiawan, 2013). Along with the rapidly growing population and lack of awareness of the importance of mangrove forests, this has resulted in a $50 \%$ reduction in mangrove population over the last 30 years (Sulistiyowati, 2009).
Economic aspects for an integrated planning strategy, by calculating the economic value of the mangrove forest ecosystem, including the usage of ponds beneath mangrove stands (silvofishery system). Good planning from both ecological and economic aspects can assist in diminishing the reduction of mangrove populations.

Research on the level of society economic income has been done in the form of silvofishery about crabs (Saidah \& Sofia, 2016), shrimp (Budihastuti, 2013), fish (Lestari, 2012). Other research is related to breakwater (Indrayanti et al., 2015), ecotourism (Putra et al., 2015), mangrove biodiversity in Situbondo (Rahardjanto, 2019). Research on economic planning has been carried out in the district of West Likupang (Suzana et al., 2011), Barowa sub-district (Fidyansari \& Hastuti, 2016), Kandang Panjang sub-district (Maulida et al., 2019).

This research is the first economic planning calculations performed on the area of Kampung Blekok, this research is useful as an information source from an economic point of mangrove forest in Kampung Blekok. Based on the explanation above, it is necessary to do calculations related to the economic aspects of the mangrove forest. Therefore, this research aims to determine the value of direct, indirect and optional economic benefits, and to determine the value of the total economic benefits from the economy of the mangrove ecosystem. 


\section{RESEARCH METHOD}

The research was conducted in February - April 2020. This research was conducted in the Kampung Blekok, located in Klatakan sub-district, Kendit district, Situbondo, East Java (Figure 1).

Tools and materials used in the form of questionnaires. The type of data used in this study are primary data and secondary data. Primary data obtained from direct observation, using the interview method in the form of a questionnaire that has been arranged. Secondary data sources were obtained from the local government of the Environment Agency of Situbondo and the Tourism Awareness Group for Kampung Blekok, as well as data from publications and previous research results that have been conducted (literature study).

The determination of respondents was done by using the technique of purposive sampling data collection. Purposive sampling method of sampling is not random but is based on certain considerations intentionally. The samples are the Area Superintendents of the Kampung Blekok Tourism, fishermen, and local people who used mangrove forest for their daily needs. The type of interview used is in the form of open interviews, namely interviews that are conducted without keeping information about the sources secret and have questions that are not limited to or are not bound by the answers.

\section{Direct Benefit (DB)}

Direct benefit is the value generated from direct use of mangrove forest such as crab fishing and tourism. Direct benefit comes from the market value approach, that is directly traded that is mostly used to determine the monetary value for the direct benefits of the mangrove ecosystem (Fauzi, 2014).

Value of direct benefit to crab (DB1) =

Information:

$$
\text { ( } \mathrm{T} \times \mathrm{H}) \text { - B (IDR/Ha/year) }
$$

$$
\begin{array}{ll}
\mathrm{T} & =\text { The result of the catch }(\mathrm{kg} / \mathrm{Ha} / \text { year) } \\
\mathrm{H} & =\text { Selling price (IDR/kg) } \\
\mathrm{B} & =\text { Operational Costs (IDR) }
\end{array}
$$

The value of direct benefit in ecotourism (DB2) is sought with the income from tourists subtracted by the expenses for maintenance of ecotourism facilities in Kampung Blekok.

After finding the direct benefit value for each element found, it is inserted into the formula (Harahab, 2010) :

$\mathrm{DB}=\mathrm{DB} 1+\mathrm{DB} 2+\ldots+\mathrm{DBn}$ (put into IDR value)

Information:

DB $=$ Direct Benefit

DB1 $=$ Direct Benefit to Crab

DB2 $=$ Direct Benefit of Ecotouris

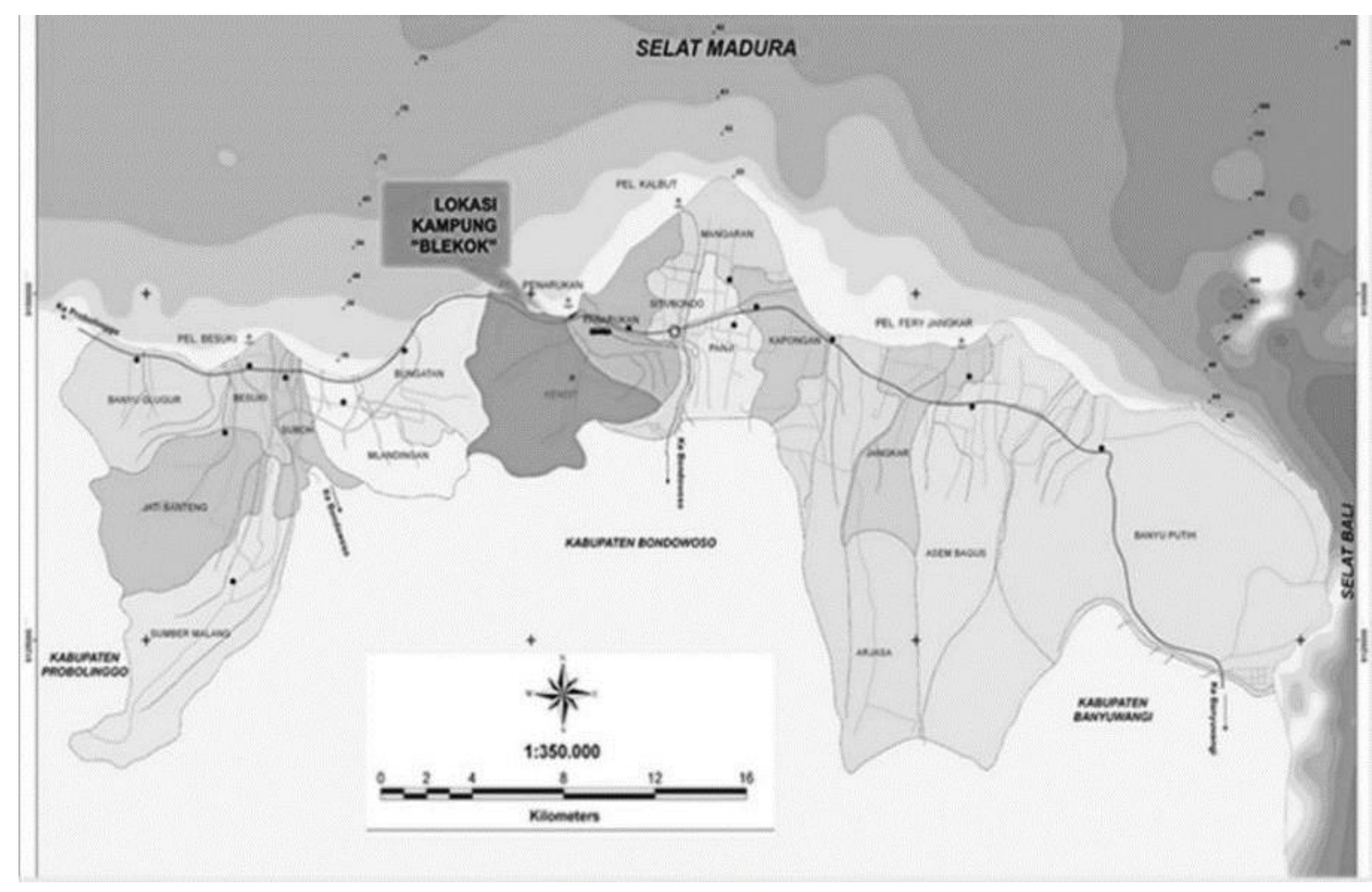

Figure 1 Map of Kampung Blekok Area 


\section{Indirect Benefit (IB)}

Indirect benefit is the value that is felt indirectly on goods and services that are produced by resources and the environment. The indirect benefit of mangrove forest is obtained from an indirect ecosystem such as a barrier to coastal abrasion and a provider of organic material for the biota that live in it. These benefits include: (1) Physical benefit, as wave absorbers are estimated through the breakwater making approach (IB1) obtained from interview with mangrove forest area superintendents. (2) Biological Benefit, as a place to provide food (feeding ground). The function of mangrove forests is as a feed provider (feeding ground) for various types of biota such as type of catch fish. This benefit can be approximated by the amount of fish caught in the waters around the mangrove forest subtracted by investment and operational costs (assuming this function is equally distributed).

The value of fish is calculated based on the number of catches per year multiplied by the total selling price using the formula (Fauzi, 2014) :

Value of indirect benefit to fish (IB2) $=$

Information:

$$
\text { (T } \times \text { H) - B (IDR/Ha/year) }
$$

$\mathrm{T}=$ The result of the catch $(\mathrm{kg} / \mathrm{Ha} /$ year $)$

$\mathrm{H}=$ Selling price (IDR $/ \mathrm{kg}$ )

$\mathrm{B}=$ Operational Costs (IDR)

After finding the direct benefit value for each element found, it is inserted into the formula (Harahab, 2010) :

$\mathrm{IB}=\mathrm{IB} 1+\mathrm{IB} 2+\ldots+\mathrm{IBn}$ (put into IDR value)

Information:

IB $=$ Indirect Benefit

IB1 = Indirect Benefit as a breakwater

IB2 = Indirect Benefit a natural feed provider for various types of biota that live in it.

\section{Optional Value (OP)}

The optional value for mangrove forest usually uses the benefit transfer method, by assessing the estimated benefits from another place (where resources are available) and transferring these benefits to obtain a coarse estimate of the benefits from the environment. The method is approached by calculating the amount of biodiversity value in the mangrove forest ecosystem. According to Rönnbäck (1999), Indonesia's mangrove forests have biodiversity of US $\$ 1500$ per $\mathrm{km}^{2}$. This value can be obtained in all mangrove forest ecosystems in Indonesia if the mangrove forest ecosystem is ecologically important and is maintained naturally. This value of the optional benefits is obtained by the equation: $\mathrm{OP}=\mathrm{US} \$ 1500$ per $\mathrm{km}^{2} \mathrm{x}$ mangrove forest area

Information:

$\mathrm{OP}=$ Optional Value

$1 \mathrm{ha}=0.01 \mathrm{~km}^{2}$

\section{Total Economic Value (TEV)}

This approach is the sum of the use and non-use values of mangrove forests that have been identified and quantified. Total Economic Value is formulated as follows (Harahab, 2010):

$$
\mathrm{TEV}=\mathrm{DB}+\mathrm{IB}+\mathrm{OP}
$$

Information:

$\begin{array}{ll}\text { TEV } & =\text { Total Economic Value } \\ \text { DN } & =\text { Direct Benefit Value } \\ \text { IB } & =\text { Indirect Benefit Value } \\ \text { OV } & =\text { Optional Value. }\end{array}$

\section{RESULT AND DISCUSSION}

\section{Direct Benefit Value (DB)}

The direct benefit value of the mangrove forest in Kampung Blekok with an area of $6.3 \mathrm{Ha}$ is calculated in direct use by the community, namely fish and ecotourism

\subsection{Crabs Value}

Mangrove crabs will come out of hiding sometime after sunset and move throughout the night primarily in search of food. When the sun will rise, the mangrove crabs go back hiding, so the mangrove crabs are classified as nocturnal animal. In foraging for food, mangrove crabs prefer to crawl. Crabs prefer natural foods in the form of algae, animal cadavers and crustaceans (Soim, 1994).

The type of crab caught is mangrove crab (Scylla serrata), crab seekers look for crabs from 5 am to 12 noon every 5 times a week. The tool used was a selfmade 2-meter-long iron stick. The way to use it is only by looking for a crab hole or nest and then stabbing it until the crab comes out. The catch of crabs is sold every day to collectors or sold to local people at a price of IDR 25.000 per kilogram (Table 1).

Table 1. Details of Crab Catching with a Mangrove Area of 6.3 Ha.

\begin{tabular}{lll}
\hline Num. & Information & Result \\
\hline 1 & Number of Respondents & 2 \\
2 & Total Production & $960 \mathrm{Kg}$ \\
3 & Price & IDR 25.000/kg \\
4 & Total Operating Costs & IDR 30.000/year \\
\hline Total Crab Values & IDR 23.970.000,00/ year. \\
\hline
\end{tabular}




\subsection{Ecotourism Value}

Ecotourism that is presented by Kampung Blekok is kind of outdoor tourism that presents natural scenery with photo spot facilities, culinary tours, experience of riding a boat around the mangrove coast, souvenirs made by the surrounding society, and information about types of mangroves and water birds that live in mangrove forests.

The mangrove value calculated in the form of income from tourists is subtracted by the expenditure budget for facility maintenance, so that the ecotourism value can be converted into IDR. 259.283.450,00 per year. The opening of the Kampung Blekok as a tourism area in 2017 and the establishment of this ecotourism area had a major impact on the income of the surrounding people. In the survey data analysis of the ecotourism development plan situation in Kampung Blekok that was done in 2018, It was found that $81 \%$ of the Kampung Blekok's villager received benefits from ecotourism development in the form of increasing new employments and increasing residents' income, while $19 \%$ said they could receive benefits from ecotourism development in the form of areas becoming more wellknown, developed, lots of tourists, beautiful.

\section{Indirect Benefit Value (IB)}

\subsection{Physical Benefits}

The benefits of mangrove forest as an abrasion barrier cannot be calculated directly because it has no market price value. To calculate the useful value of mangrove forest as an abrasion barrier, it can be estimated using replacement costs by constructing a breakwater (Putera \& Sallata, 2015).

The results of the data obtained on the construction of the breakwater in the Kampung Blekok with a size of $118 \mathrm{~m} \times 2.5 \mathrm{~m} \times 1 \mathrm{~m}(l \times w \times h)$ and 10 years of durability is IDR 633.660.000,00. So to get the value per year divided by 10 , the result is IDR 63.366.000,00 per year.

The beneficiaries of this water breaker are the community and also the local government of the Blekok Village Area. The people of Kampung Blekok have benefited from the construction of the breakwater after it was built within 2 years. Breakwater can hold sea water so it doesn't cause flooding when the tide occurs and the coastal areas are not eroded by sea water.

\subsection{Biological Benefits}

It is estimated that $70 \%$ of the life cycle of shrimp and fish caught in the estuary area is in the mangrove area (Soeroyo \& Sudjoko, 1993). According to Rönnbäck (1999) various types of aquatic biota are associated with mangroves, including fish, crustaceans and mollusks. Generally, these species live permanently and spend their entire life cycle in the mangrove area. There are also species that only live temporarily and associated with the mangrove on the part of their life cycle. There are only a few types of fish that live permanently in mangroves, but most of the marine biota make mangroves as a nurture area.

The types of fish caught by fishermen in the coastal areas of Kampung Blekok are Kurisi, Teri, and Squid. Catching fish in the form of nets or fishing hooks using a personal boat. Usually fishing takes time around 5 AM to $12 \mathrm{PM}$, but sometimes around $7 \mathrm{PM}$ to $8 \mathrm{PM}$. Catching fish is not every day, people also work in the paddy fields, as shell craftsmen, and also become employees at Kampung Blekok Tourism. Fishermen went to fish on average 4 times a week, this is due to several factors: the bad weather because of the unstable sea waves and also the rainy season. Most of the fishermen's boats are personal property, but there are also boats given from the tourism agency to facilitate Kampung Blekok Tourism as one of the tourist facilities that are served.

The catching results obtained are then sold to collectors, but if the results are only a few, then it is only sold to local residents or for their own consumption. The value of direct benefit in fishing in Kampung Blekok with an area of 6.3 Ha is IDR 681.284.900,00 per year. Odum (1993) proved that the mangrove ecosystem is an ideal area for several species of fish (especially young), known as a nursery and feeding ground. In addition, Chong et al. (1990) also reported that mangrove waters are a place to find food during high tides for both economic and non-economic fish. The fish community in mangrove waters is dominated by several species, although the fish species caught are relatively numerous, and generally still have juvenile size.

Table 2. Details of fish catching with a mangrove area of $6.3 \mathrm{Ha}$.

\begin{tabular}{cll}
\hline Num. & Information & Result \\
\hline 1 & Number of Respondents & 14 \\
2 & Total Production & $38.888 \mathrm{~kg}$ \\
3 & Price & IDR $18.000 / \mathrm{kg}$ \\
4 & Total Operating Cost & IDR $18.699 .100,00 /$ year \\
\hline Total Biological Benefit & IDR $681.284 .900,00 /$ year \\
\hline
\end{tabular}


Table 3. Total Economic Value of Mangrove Forest Tourism in Kampung Blekok with an area of 6.3 Ha.

\begin{tabular}{|c|c|c|}
\hline Num. & Types of Benefit & Benefit Value \\
\hline 1. & Direct Benefit (DB) & IDR $940.568 .350,00$ \\
\hline 2. & Indirect Benefit (IB) & $87.336 .000,00$ \\
\hline 3. & Optional Vale (OP) & $1.399 .923,00$ \\
\hline \multicolumn{2}{|c|}{ Total Economic Value } & IDR 1.027.904.350,00 \\
\hline
\end{tabular}

Food availability and suitable spawning areas are factors that support the abundance of squid resources in the mangrove forest of Kampung Blekok according to Rönnbäck (1999) various types of aquatic biota associated with mangroves, including fish, crustaceans and mollusks. Generally, these species live permanently and spend their entire life cycle in the mangrove area. There are also species that only live temporarily and associated with the mangrove on the part of their life cycle. There are only a few types of fish that live permanently in mangroves, but most of the marine biota make mangroves as a nurture area. Squid is a type of mollusk that uses mangrove waters as a nurture and foraging area.

\section{Optional Value (OP)}

The optional benefits of mangrove forest are calculated from the benefit of biodiversity. According to Ruitenbeek (1991) the biodiversity value in Bintuni, Irian Jaya Bay of US $\$ 1.500$ per $\mathrm{km}^{2}$ per year can be used for Indonesian mangrove forests. The optional value is obtained by multiplying the biodiversity value by US $\$$ 1.500 per $\mathrm{km}^{2}$ per year or US $\$ 15$ per Ha per year with an exchange rate of Rupiah toward the dollar of IDR $14.814,00$ (22 September 2020), then the value gained is IDR $222.210,00 / \mathrm{Ha} /$ year, then multiplied by the mangrove forest area of $6.3 \mathrm{Ha}$, so the value of optional benefits found is IDR 1.399.923,00 per year.

\section{Total Economic Value (TEV)}

The total economic value comes from the sum of the value of direct benefits (DB), value of indirect benefits (IB) and also the value of options (OP). The total economic value produced by the mangrove forest area of Kampung Blekok is IDR 1.027.904.350,00/year (Table $3)$.

Based on a comparison of the total economic value of the mangrove ecosystem from several studies, various results were obtained. The differences that occur in each of similar studies include changes in the rupiah exchange rate against the dollar (US \$), the extent of the mangrove ecosystem, differences in prices, and the diversity of the utilization in the mangrove ecosystem. According to Setiyowati (2016), the value of benefits obtained in economic valuation studies may change in the future, due to changes in the type of utilization, especially the direct benefit values calculated on the basis of extractive utilization of biological resources that have taken place in the research location until recently. According to Ariftia et al. (2014), if the indirect value contribution is high, it proves that mangrove forests have very high intangible benefits (service and environmental values), so the importance of estimating the economic value of mangrove forests into the rupiah value so that the public knows how large the ecological value of mangrove forests has been neglected because they are considered to have no market value.

The comparison of the results obtained can be seen in the extent of the mangrove forest and also the supporting variables studied in the form of the variables of direct benefit, indirect benefit and optional benefit. The results obtained will of course increase or decrease depending on the surrounding people in utilizing mangrove forests in terms of fishing, catching crabs, ecotourism and also protecting mangrove forests so that the function of the mangrove forest itself is still maintained. When compared with previous studies, the total economic value in Kampung Blekok was IDR 1.027.904.350.00 with an area of $6.3 \mathrm{Ha}$, can be said that it is large

\section{CONCLUSION}

The economic valuation of mangrove forests from the results of the research conducted, obtained the following results: (1) the value of direct use is IDR 681.284.900,00 per year that is obtained from crab catches and ecotourism. (2) The value of indirect use is IDR $87.336 .000,00$ per year that is obtained from the catch of fish and the manufacture of breakwaters. (3) The optional value is IDR $1.399 .923,00$ per year with a value of IDR 14.814,00. (4) The total economic value produced by the mangrove forest of Kampung Blekok is IDR 1.027.904.350,00 per year.

\section{REFERENCES}

Ariftia, R. I., Qurniati, R., \& Herwanti, S. 2014. Total Economic Value of Mangrove Forest in Margasari Village Sub District of Labuhan Maringgai District of Lampung Timur. Jurnal Kehutanan Fakultas Pertanian, 2 (3), 19-28.

Budihastuti, R. 2013. Pengaruh Penerapan Wanamina Terhadap Kualitas Lingkungan Tambak dan Pertumbuhan Udang di Kota Semarang. Prosiding Seminar Nasional Pengelolaan Sumberdaya Alam Dan Lingkungan, ISBN 978-602-17001-1-2, 374377.

Buwono, Y. R., Ardhana, I. P. ., \& Sudarma, M. 2015. Potensi Fauna Akuatik Ekosistem Hutan Mangrove Di Kawasan Teluk Pangpang Kabupaten 
Banyuwangi. ECOTROPHIC: Jurnal Ilmu Lingkungan (Journal of Environmental Science), 9(2), 28. https://doi.org/10.24843/ejes.2015.v09.i02.p05

Chong, V. C., Sasekumar, A., Leh, M. U. C., \& D'Cruz, R. 1990. The fish and prawn communities of a Malaysian coastal mangrove system, with comparisons to adjacent mud flats and inshore waters. Estuarine, Coastal and Shelf Science, 31(5), 703722. https://doi.org/10.1016/0272-7714(90)90021-I

Fauzi, A. 2014. Valuasi Ekonomi dan Penilaian Kerusakan Sumberdaya Alam dan Lingkungan. IPB Press.

Fidyansari, D., \& Hastuti, S. 2016. Valuasi ekonomi ekosistem mangrove di Desa Barowa Kecamatan Bua Kabupaten Luwu. Perbal: Jurnal Pertanian Berkelanjutan, 4(3), 1-14.

Hairunnisa, S. K., Gal, M. A., \& Soewarni, I. 2018. Valuasi Ekonomi Hutan Mangrove Provinsi Sulawesi Utara. 3(1), 17-22.

Harahab, N. 2010. Pemetaan Hutan Mangrove Serta Nilai Ekonomi Barang Dan Jasa Lingkungan Yang Dihasilkan. Kehutanan Tropika Humida, 3(2), 183190.

Indrayanti, M. D., Fahrudin, A., \& Setiobudiandi, I. 2015. Penilaian Jasa Ekosistem Mangrove di Teluk Blanakan Kabupaten Subang. Jurnal Ilmu Pertanian Indonesia, 20(2), 91-96. https://doi.org/10.18343/jipi.20.2.91

Lestari, I. 2012. Hasil produksi menggunakan sistem pengelolaan tambak silvofishery dan non silvofishery di Desa Tanjung Rejo Kecamatan Percut Sei Tuan. (Doctoral Dissertation, UNIMED)., 22, 1-7. http://eprints.unwahas.ac.id/2196/

Maulida, G., Supriharyono, \& Suryanti. 2019. Valuasi Ekonomi Pemanfaatan Ekosistem Mangrove di Kelurahan Kandang Panjang Pekalongan Provinsi Jawa Tengah. Journal Of Maquares, 8(9), 113-138.

Odum, E. P. 1993. Dasar-dasar Ekologi (Edisi Keti). Gadjah Mada University Press.

Putera, F. H. A., \& Sallata, A. E. 2015. Valuasi Ekonomi Sumberdaya Di Teluk Palu, Kota Palu, Provinsi Sulawesi Tengah. Jurnal Kebijakan Sosial Ekonomi Kelautan Dan Perikanan, 5(2), 83. https://doi.org/10.15578/jksekp.v5i2.1019
Putra, A. C., Anggoro, S., \& Kismartini. 2015. Strategi Pengembangan Ekowisata Melalui Kajian Ekosistem Mangrove Di Pulau Pramuka, Kepulauan Seribu (Ecotourism Development Strategy with Mangrove Ecosystem Studies at Pramuka Island, Kepulauan Seribu). SAINTEK PERIKANAN : Indonesian Journal of Fisheries Science and Technology, 10(2), 91-97. https://doi.org/10.14710/ijfst.10.2.91-97

Rahardjanto, A. 2019. Biodiversitas dan Fungsi Ekosistem Mangrove di Taman Nasional Baluran (Analisis Struktur dan Fungsi Ekosistem Peralihan).

Rönnbäck, P. 1999. The ecological basis for the economic value of mangrove forests in seafood production. Ecological Economics, 29, 235-252.

Ruitenbeek, H. J. 1991. Indicators of Ecologically Sustainable Development: Towards New Fundamentals.

Saidah, S., \& Sofia, L. A. 2016. Pengembangan Usaha Pembesaran Kepiting Bakau (Scylla spp) melalui sistem Silvofishery. Jurnal Hutan Tropis, 4(3), 265272.

Sambu, A. H., Sribianti, I., \& Chadijah, A. 2018. Model Pengelolaan Mangrove Berbasis Ekologi Dan Ekonomi.

Setiawan, H. 2013. Status Ekologi Hutan Mangrove Pada Berbagai Tingkat Ketebalan. Jurnal Penelitian Kehutanan Wallacea, 2(2), 104. https://doi.org/10.18330/jwallacea.2013.vol2iss2pp10 4-120

Setiyowati, D. 2016. Valuasi Ekonomi Sumberdaya Mangrove di Kelurahan Mangunharjo, Kecamatan Tugu, Kota Semarang. 68-70.

Soeroyo, D. A., \& Sudjoko, B. 1993. Dukungan mangrove terhadap keberadaan ikan dan udang di Teluk Bintuni, Irian Jaya. Prosiding Simposium Perikanan II, 14-23.

Soim, A. 1994. Pembesaran Kepiting. Penebar Swadaya. Sulistiyowati, H. 2009. Biodiversitas Mangrove di Cagar Alam Sempu. Jurnal Sainstek, 8(1), 59-60.

Suzana, B. O. L., Timban, J., Kaunang, R., \& Ahmad, F. 2011. Valuasi Ekonomi Sumberdaya Hutan Mangrove Di Desa Palaes Kecamatan Likupang Barat Kabupaten Minahasa Utara. Agri-Sosioekonomi, 7(2), 29. https://doi.org/10.35791/agrsosek.7.2.2011.89 